\title{
Contributors
}

TOм вAKER is Professor of Law at the University of Pennsylvania Law School. He is the author of The Medical Malpractice Myth (2005) and Insurance Law and Policy: Cases, Materials and Problems (2008).

KeEBet Von Benda-BeCKMAnn is the head of the Project Group Legal Pluralism at the Max Planck Institute for Social Anthropology in Halle, Germany. Her most recent publications include Order and Disorder: Anthropological Perspectives (2007) (ed. with F. Pirie) and Social Security between Past and Future: Ambonese Networks of Care and Support (2007) (with F. von Benda-Beckmann).

ANNE BLOOM is Associate Professor of Law at the University of the Pacific McGeorge School of Law. A former public interest attorney, she has published articles on mass torts, the plaintiffs' bar, and the role of tort law in shaping sexual identity.

MARTHA CHAMALlas holds the Robert J. Lynn Chair in Law at the Moritz College of Law at Ohio State University, where she received the University Distinguished Lecturer Award in 2007. She is the author of Introduction to Feminist Legal Theory, 2nd ed. (2003) and a forthcoming book (with Jennifer Wriggins), The Measure of Injury: Race, Gender, and the Law of Torts.

DAVID M. ENGEL is SUNY Distinguished Service Professor of Law at the University at Buffalo Law School. A former president of the Law \& Society Association, his publications include Rights of Inclusion: Law and Identity in the Life 
Stories of Americans with Disabilities (2003) (with Frank W. Munger), which received the Myers Outstanding Book Award.

CHARles R. EPP is Associate Professor of Public Administration at the University of Kansas. His book, The Rights Revolution (1998), won the American Political Science Association's C. Herman Pritchett Award.

ERIC A. FELDMAN is Professor of Law at the University of Pennsylvania Law School. He is the author of Blood Feuds: AIDS, Blood, and the Politics of Medical Disaster (ed. with Ronald Bayer) (1999), The Ritual of Rights in Japan: Law, Society, and Health Policy (200o), and Unfiltered: Conflicts over Tobacco Policy and Public Health (with Ronald Bayer) (2004).

MARC GALANTER is the John \& Rylla Bosshard Professor Emeritus of Law and South Asian Studies, University of Wisconsin-Madison and Centennial Professor, Department of Law, London School of Economics and Political Science. A former president of the Law \& Society Association, his books include Competing Equalities: Law and the Backward Classes in India (1984 and 1991), Law and Society in Modern India (1989), and Lowering the Bar: Lawyer Jokes and Legal Culture (2005).

william надтом is Professor in the Department of Government and Politics at the University of Puget Sound. He is the author of Reporting on the Courts and (with Michael McCann) the multi-award winning Distorting the Law: Politics, Media, and the Litigation Crisis (2004).

VALERIE P. HANS is Professor of Law at Cornell Law School. Her books include American Juries: The Verdict (2007), The Jury System: Contemporary Scholarship (2006), Business on Trial: The Civil Jury and Corporate Responsibility (2000), and Judging the Jury (1986).

LYN MATHER is Director of the Baldy Center for Law \& Social Policy and Professor of Law and Political Science at the University at Buffalo, State University of New York. Her co-authored book, Divorce Lawyers at Work: Varieties of Professionalism in Practice (2001) won the C. Herman Pritchett award from APSA. She has served as president of the Law \& Society Association and chair of the Law and Courts Section of APSA. 
MiCHAEL MCCANN is Gordon Hirabayashi Professor for the Advancement of Citizenship at the University of Washington. He is director of the Law, Societies, and Justice program and the Comparative Law and Society Studies Center. McCann's books include Rights at Work: Pay Equity and the Politics of Legal Mobilization (1994) and Distorting the Law: Politics, Media, and the Litigation Crisis (2004), each of which has won multiple awards.

DAVID NELKEN is Distinguished Professor of Legal Institutions and Social Change at the University of Macerata in Italy. He is also Distinguished Research Professor of Law at the University of Wales, Cardiff, and Honorary Professor of Law at the LSE, United Kingdom, and "Wiarda" Chair in the Faculty of Law, Utrecht, The Netherlands. Recent publications include Comparative Law: A Handbook (2007), European Ways of Law (2007), and Exploring Legal Cultures (2007).

NANCY REICHMAn is Professor and Chair of the Sociology and Criminology Department at the University of Denver. She is the co-author of Ozone Connections: Expert Networks in Global Environmental Governance (2002).

ANN SCALES is a Professor of Law at the University of Denver College of Law. She is the author of Legal Feminism: Activism, Lawyering, and Legal Theory (2006).

JOyCe STERLING is Professor of Law at University of Denver Sturm College of Law. Her publications include After the JD: First Results of a National Study of Legal Careers (2004).

TAKao tanase is Professor at Chuo Law School. He has published numerous books and articles in Japanese and English, including Contract and its Related Practices (1999) and Civil Society and Responsibility (2007). In 2005, his work was honored with a series of papers at the Sho Sato Conference, Boalt Hall School of Law, University of California, Berkeley.

JENNIfER B. WRiggins is the Sumner T. Bernstein Professor at the University of Maine School of Law. She is currently working on a book with Martha Chamallas The Measure of Injury: Race, Gender, and the Law of Torts. 



\section{FAULT LINES}


